\title{
Mapping the Vulnerability of Covid-19 in Sumatera Barat Based on Population Density
}

\author{
Fadillah Ulva ${ }^{1, *}$ Wilda Tri Yuliza ${ }^{2}$
}

\author{
${ }^{1}$ Public Health, STIKes Alifah Padang, Padang, Indonesia \\ ${ }^{2}$ Public Health, STIKes Alifah Padang, Padang, Indonesia \\ *Corresponding author. Email: fadillah.ulva21@gmail.com
}

\begin{abstract}
All areas in Sumatera Barat have been exposed to Covid-19 with a distribution of high, medium, and low risk. Population density are considered to be the driving factors for the spread of Covid-19. The purpose of this study was to see an overview of the Covid-19 spreading by population density factor. This research was a descriptive study assisted by the application of Geographic Information System (GIS). The data used was secondary data obtained from Sumatera Barat Health Department and Statistic of Sumatera Barat Province. Data analyzed by univariate analysis. The result showed that the highest cases of Covid-19 in Padang (14.557 cases). The highest population density is in Bukittinggi (4795.09 people $\left./ \mathrm{km}^{2}\right)$. For the government, reviewing the social restrictions policy largescale/enforcement of restrictions on community activities for considering tightening health protocols, maximum capacity, and rules of operating hours in places that have the potential to occur crowd of people.
\end{abstract}

Keywords: covid-19, population density

\section{INTRODUCTION}

The Novel Coronavirus Disease (Covid-19) is a highly pathogenic, infectious and invasive pneumonia caused by a virus. The first case of mysterious pneumonia was reported in Wuhan, Hubei Province, China in December 2019. WHO received information about an as yet unidentified epidemic. In early 2020, the epidemic was officially named Covid-19 and was recognized as an infectious disease that could result in a state of emergency. On December 18-29 2019, five patients were reported to be treated with Acute Respiratory Distress Syndrome (ARDS). This case increased rapidly until early January 2020 with 44 cases reported. In addition, with a fast time, this disease has spread in various other areas such as Thailand, Japan, South Korea.[1]

The virus can be passed from person to person and has spread widely in China and more than 190 other countries and territories. On March 12, 2020, WHO declared Covid-19 a pandemic. As of October 12, 2020, 216 countries have been confirmed to be exposed to Covid-19, of which there are 17,660,523 cases and 680,894 deaths worldwide. Meanwhile, in Indonesia, 336,716 positive cases of Covid-19 and 11,935 deaths have been confirmed. Within months, Covid-19 had spread throughout Indonesia, including Sumatera Barat. The first positive confirmed case in Sumatera Barat was announced on March 23, 2020. To date, the number of positive confirmed cases in Sumatera Barat is 8,874 cases and 181 deaths.[2]

To see a picture of the COVID-19 situation in Sumatera Barat and the population density factor, mapping the distribution of Covid-19 using spatial analysis can really help present this information better. Spatial analysis is a data analysis that is carried out on spatial data (spatial-oriented data), which can be done using a Geographic Information System (GIS). Geographic Information System is a system that is able to build, manipulate and display information that has a geographic reference. Spatial analysis using GIS has advantages over using only tabular data analysis, because it allows to view, to understand, to interpret and to display spatial data in many ways, showing relationships, patterns and trends spatially, in the form of maps, globes, reports and graphs.[3]

\section{MATERIAL AND METHOD}

This research is a quantitative descriptive study. Data used is secondary data obtained from Sumatera Barat Health Department and the Statistics of Sumatera 
Barat Provinces in 2020. This research was conducted in July-September 2021.

This study focuses on the population factor as an indicator of the spread of Covid-19. The methods used in this study include secondary data collection, data classification, data classification test, inputting attributes of Covid-19 case variables, population density variables in visual form, scoring data processing methods, overlays, statistical analysis, distribution pattern analysis and analysis map qualitatively. The unit of analysis used is district/city administration. Classification of each level of vulnerability is given a score based on the cut of points with quartiles, a score of 1 for high vulnerability, a score of 2 for moderate vulnerability and a score of 3 for low vulnerability. Processing attribute variables with GIS software to determine the level of vulnerability and the extent of vulnerability to population density so as to produce a map of the Covid-19 vulnerability level in Sumatera Barat in 2020.

\section{RESULT}

Covid-19 case in Sumatera Barat (April-December) was presented in Table 1. Based on Table 1, it can be seen that the total number of Covid-19 cases in Sumatera Barat in April - December 2020 in Sumatera Barat amounted to 29.380 cases. Cases with the $3^{\text {rd }}$ highest in Sumatera Barat are Padang (50\%), Agam (7\%), and Pesisir Selatan (4\%). While the lowest cases is Pasaman (1\%). Spatial analysis of Covid-19 Cases are shown in Figure 1.

Table 1. Frequency Distribution of Covid-19 by City/District in Sumatera Barat (April-December 2020)

\begin{tabular}{|l|l|r|r|r|}
\hline No. & City/District & \multicolumn{1}{|c|}{ Cases } & \multicolumn{1}{|c|}{ Score } \\
\hline 1 & Agam & 2042 & $7 \%$ & 1 \\
\hline 2 & Dharmasraya & 558 & $2 \%$ & 3 \\
\hline 3 & $\begin{array}{l}\text { Kepulauan } \\
\text { Mentawai }\end{array}$ & 474 & $2 \%$ & 3 \\
\hline 4 & Limapuluh Kota & 578 & $2 \%$ & 2 \\
\hline 5 & Padang & 1156 & $4 \%$ & 2 \\
\hline 6 & Pariaman & & & 3 \\
\hline 7 & Pasaman Barat & 571 & $2 \%$ & 2 \\
\hline 8 & Pesisir Selatan & 1255 & $4 \%$ & 1 \\
\hline 9 & Sijunjung & 846 & $3 \%$ & 2 \\
\hline 10 & Solok & 859 & $3 \%$ & 2 \\
\hline 11 & Solok Selatan & 471 & $2 \%$ & 3 \\
\hline 12 & Tanah Datar & 1224 & $4 \%$ & 1 \\
\hline 13 & Bukittinggi & 1149 & $4 \%$ & 1 \\
\hline 14 & Padang & 14557 & $50 \%$ & 1 \\
\hline 15 & Padang Panjang & 824 & $3 \%$ & 2 \\
\hline 16 & Pariaman & 582 & $2 \%$ & 2 \\
\hline 17 & Payakumbuh & 783 & $3 \%$ & 2 \\
\hline 18 & Sawahlunto & 401 & $1 \%$ & 1 \\
\hline 19 & Solok & 696 & $2 \%$ & 2 \\
\hline & Tota & 29.380 & $100 \%$ & \\
\hline
\end{tabular}

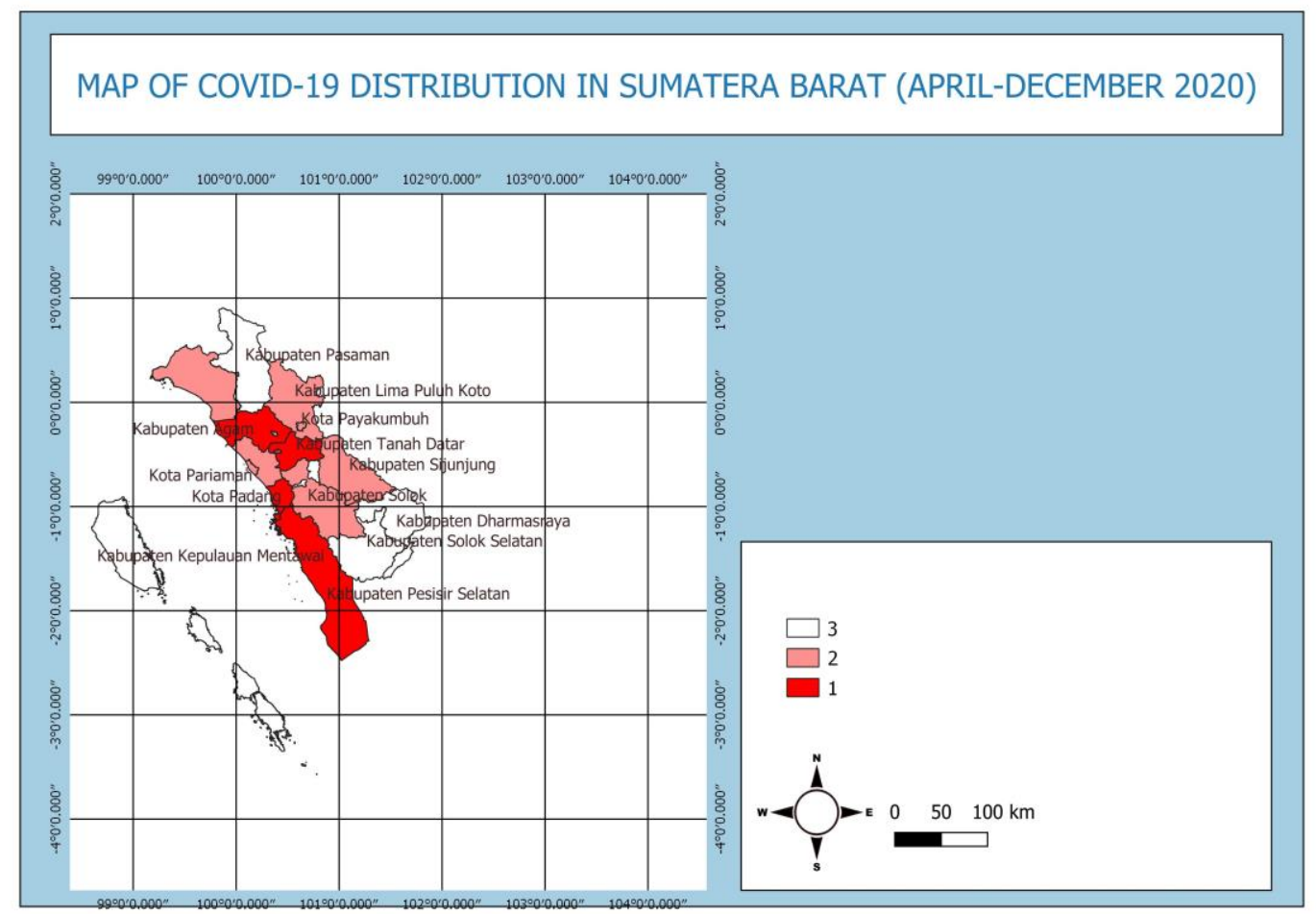

Figure 1. Map of the Distribution of Covid-19 Cases in Sumatera Barat (April-December 2020) 
Based on table 2, it can be seen that population density in Sumatera Barat is quite varied. The highest population density is in Bukittinggi (4795.09 people/sq.km). The lowest population density is Kepulauan Mentawai (14.58 people/sq.km). Padang, Agam, Padang Panjang, and Payakumbuh are areas with a high population density in Sumatera Barat. Spatial analysis of Population Density in Sumatera Barat are shown in Figure 2.

Table 2. Frequency Distribution of Population Density in Sumatera Barat (2020)

\begin{tabular}{|l|l|r|r|r|}
\hline No. & \multicolumn{1}{|c|}{ City/District } & $\begin{array}{c}\text { Population } \\
\text { Density }\end{array}$ & $\%$ & Score \\
\hline 1 & Agam & 293.26 & $2 \%$ & 3 \\
\hline 2 & Dharmasraya & 77.20 & $1 \%$ & 3 \\
\hline 3 & Kepulauan Mentawai & 14.58 & $0 \%$ & 3 \\
\hline 4 & Limapuluh Kota & 107.40 & $1 \%$ & 3 \\
\hline 5 & Padang Pariaman & 323.17 & $2 \%$ & 3 \\
\hline
\end{tabular}

\begin{tabular}{|c|c|c|c|c|}
\hline 6 & Pasaman & 75.96 & $1 \%$ & 3 \\
\hline 7 & Pasaman Barat & 111.03 & $1 \%$ & 3 \\
\hline 8 & Pesisir Selatan & 87.73 & $1 \%$ & 3 \\
\hline 9 & Sijunjung & 75.08 & $1 \%$ & 3 \\
\hline 10 & Solok & 104.73 & $1 \%$ & 3 \\
\hline 11 & Solok Selatan & 54.40 & $0 \%$ & 3 \\
\hline 12 & Tanah Datar & 278.20 & $2 \%$ & 3 \\
\hline 13 & Bukittinggi & 4795.09 & $33 \%$ & 1 \\
\hline 14 & Padang & 1310.50 & $9 \%$ & 1 \\
\hline 15 & Padang Panjang & 2448.30 & $17 \%$ & 1 \\
\hline 16 & Pariaman & 1424.83 & $10 \%$ & 2 \\
\hline 17 & Payakumbuh & 1637.83 & $11 \%$ & 1 \\
\hline 18 & Sawahlunto & 280.85 & $2 \%$ & 3 \\
\hline 19 & Solok & 1030.13 & $7 \%$ & 2 \\
\hline \multicolumn{2}{|c|}{ Total } & 29.380 & $100 \%$ & \\
\hline
\end{tabular}

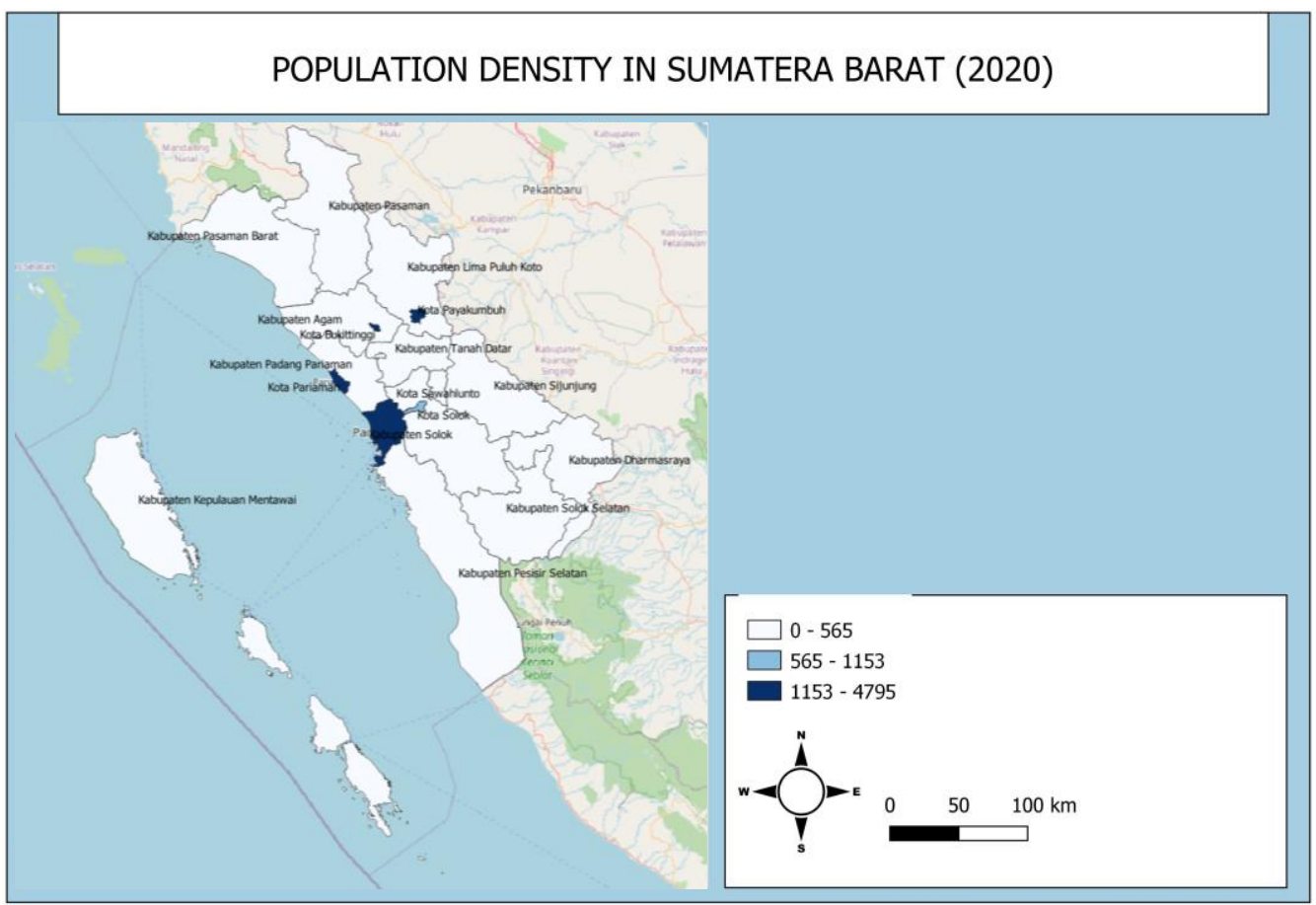

Figure 2. Map of population density in Sumatera Barat (April-December 2020)

\section{DISCUSSION}

On the Covid-19 vulnerability map based on population density with a graph of positive confirmed cases of COVID-19 presented, it is not always in areas with high density that there is a high number of confirmed cases of COVID-19 as well. In this case, the location factor and the interaction between regions are important factors in the spread of the virus. International trade and travel has the potential to contribute to a worldwide pandemic.[4] This statement is in accordance with the spread of COVID-19 cases in the Padang City area which is the capital of Sumatera Barat province with very high community mobility. Padang as the entry point for Sumatera Barat both from land, air and sea is one of the factors causing the high COVID-19 vulnerability in this city.

This study found 3 cities with a high level of Covid19 vulnerability, Padang, Bukittinggi and Payakumbuh. Population density is one of the risk factors for the 
transmission of Covid-19. Densely populated urban areas will certainly cause faster disease transmission with a more compact and complex distribution chain. Sub-urban areas have lower outbreaks, but suburban areas also have inadequate health facilities to deal with disease outbreaks, especially COVID19, which is a new disease.

Residents living in suburban areas have challenges in the form of remote access to hospitals with complete facilities and adequate capacity. Urban areas can easily implement policies such as physical distancing and prohibition of mass gatherings to outsmart population density; but not so for the suburbs. Outskirts can experience difficulties in circumventing the disparity in health facilities they experience. However, there are also cases where population density does not necessarily contribute to the positive number of COVID19. This can be caused by other factors that need to be studied more deeply.[5]

Based on the population density map marked by the density dot and the number of positive COVID19 per City Administration, we can know that so far in Indonesia there has been no strong correlation between densely populated areas and the number of positive COVID19. This indicates that the population density factor is one of the catalysts but is not yet the main factor.[6]

\section{CONCLUSION}

This study found that the highest cases of Covid-19 was reported in Padang. There were 3 cities that classified into high level of Covid-19 vulnerability, Padang, Bukittinggi and Payakumbuh. There was not a strong correlation between densely populated areas and the number of positive COVID19.

\section{AUTHORS' CONTRIBUTIONS}

FU: Conception and design; writing, data analysis, editing. WTY: writing, data analysis; editing

\section{ACKNOWLEDGMENTS}

Appreciation and sincere gratitude to STIKes Alifah Padang, Sumatera Barat Health Department, Statistics of Sumatera Barat that given support, information and suggestions to authors so that this article would be finished.

\section{REFERENCES}

[1] Nasional, K. P. C.-19 dan P. E. 2020. Data Sebaran Covid-19. Komite Penanganan Covid-19 Dan Pemulihan Ekonomi Nasional. https://covid19.go.id

[2] Zoran, M. A., Savastru, R. S., Savastru, D. M., \& Tautan, M. N. (2020). Assessing the relationship between surface levels of PM2 . 5 and PM10 particulate matter impact on COVID-19 in Milan , Italy. Science of the Total Environment, 738, 139825. DOI https://doi.org/10.1016/j.scitotenv.2020.139825

[3] Araújo, M. B., \& Naimi, B. (2020). Spread of SARS-CoV-2 Coronavirus likely constrained by climate. 1-26.

[4] Neiderud, C. J., dan MD, "How urbanization affects the epidemiology of emerging infectious disease," Infection Ecolofy and Epidemiology, 2015.

[5] Edriani, Tiara Shofi, Anisa Rahmadani, D. Chiko M. Nur. Analisis Hubungan Kepadatan Penduduk dengan Pola Penyebaran Covid-19 Provinsi DKI Jakarta Regresi Robust. 2021. Indonesian Journal of Mathematics Vol 1 (2) DOI : https://doi.org/10.35472/indojam.v1i2.353

[6] Chandra S., dkk. "A geographic analysis of population density thesholds in influenza pandemic of 1918-19," International Journal of Helath Geographics. 